\title{
GC-MS-Based Metabolomic Profiles Combined with Chemometric Tools and Cytotoxic Activities of Non-Polar Leaf Extracts of Spondias mombin L. and Spondias tuberosa Arr. Cam.
}

\author{
Jhonyson A. C. Guedes, ${ }^{\circledR a, b}$ Elenilson G. Alves Filho, ${ }^{\circledR b}$ Maria F. S. Silva, ${ }^{c}$ \\ Tigressa H. S. Rodrigues, ${ }^{d}$ Christiane M. C. Ramires, ${ }^{e}$ Maria A. C. Lima, ${ }^{f}$ \\ Gisele S. Silva, ${ }^{b}$ Cláudia Ó. Pessoa,${ }^{c}$ Kirley M. Canuto, ${ }^{b}$ Edy S. Brito, ${ }^{b}$ Ricardo E. Alves, ${ }^{b}$ \\ Ronaldo F. Nascimento ${ }^{a}$ and Guilherme J. Zocolo*,b \\ ${ }^{a}$ Departamento de Química Analítica e Físico-Química, Universidade Federal do Ceará, \\ 60455-760 Fortaleza-CE, Brazil \\ ${ }^{b}$ Embrapa Agroindústria Tropical, 60511-110 Fortaleza-CE, Brazil \\ 'Departamento de Fisiologia e Farmacologia, Universidade Federal do Ceará, \\ 60430-275 Fortaleza-CE, Brazil \\ ${ }^{d}$ Universidade Estadual do Vale do Acaraú, 62040-370 Sobral-CE, Brazil \\ eEmpresa Estadual de Pesquisa Agropecuária da Paraíba (EMEPA), \\ 58013-290 João Pessoa-PB, Brazil \\ ${ }^{f}$ Embrapa Semiárido, 56302-970 Petrolina-PE, Brazil
}

\begin{abstract}
Agroindustrial residues, such as leaves of fruit plants, can be sources of bioactive molecules, thus adding value to co-products that are rarely explored in agroindustry. In this context, this study aimed to look into the phytochemical profiles in detail and to explore the antitumor potential of $S$. tuberosa and $S$. mombin leaves. We observed that, $S$. tuberosa leaf extract was cytotoxic in both tumor and healthy cells. S. mombin extracts selectively inhibited cell proliferation in the tumor cell line for prostate cancer (PC3) and did not significantly affect healthy cells. The metabolic profiles of the extracts were evaluated by gas chromatography coupled with mass spectrometry and twenty-three metabolites were identified. The correlation of metabolic profiles with cytotoxic tests indicated possible chemical markers that may be responsible for the inhibition of cell proliferation. This study revealed that the unexplored co-products in agroindustry may have great therapeutic potential, and therefore should be screened for biologically active compounds.
\end{abstract}

Keywords: metabolomics, yellow mombin, umbu, chromatography

\section{Introduction}

Spondias mombin is present in tropical zone of Africa, South America, and Asia. ${ }^{1}$ In Brazil, it is widely cultivated, mainly in the North and Northeast regions. ${ }^{2}$ Additionally, S. mombin is also found in Caribbean ${ }^{3}$ and French Polynesian islands. ${ }^{4}$ On the other hand, Spondias tuberosa is an endemic fruit tree species native to the Brazilian semiarid region. ${ }^{5}$ Commercial production of umbu is non-existent, and demand for the fruit stems from domestic extractivism. ${ }^{6}$

\footnotetext{
*e-mail: guilherme.zocolo@embrapa.br
}

Spondias tuberosa Arr. Cam. and Spondias mombin L. are representative species of tropical America, and are traditionally known in Brazil as umbu and yellow mombin, respectively. ${ }^{2,5}$ These exotic species belong to the Spondias genus of the family Anacardiaceae; ${ }^{7}$ their fruits have recognized nutritional, ${ }^{5,8}$ medicinal, ${ }^{7}$ and commercial value. ${ }^{9-11}$

Spondias has been widely used as a popular treatment for several diseases. Specifically, S. mombin has been used as a diuretic, and is also used to treat various nervous disorders. ${ }^{1}$ Further, it presents potential anti-fertility and abortifacient activities. ${ }^{12-14} S$. tuberosa has been used in digestive disorders, diarrhea, and menstrual abnormalities. ${ }^{15}$ 
In an earlier study, ${ }^{15}$ S. tuberosa ethanol extracts in rats showed antidiabetic effects. In addition, studies revealed that it also displays anti-inflammatory, antioxidant, ${ }^{16}$ and anticholinesterases activities. ${ }^{17}$ Both Spondias presents antibacterial, antimicrobial, and antiviral properties. ${ }^{18}$ $S$. tuberosa seed extracts in methanol and chloroform half maximum lethal concentration $\left(\left(\mathrm{LC}_{50}\right): 168.3\right.$ and $152.26 \mu \mathrm{g} \mathrm{mL}{ }^{-1}$, respectively $)^{16}$ showed moderate cytotoxic activity in brine shrimps.

The low cytotoxicity of Spondias demonstrated by various in vivo experimental models ${ }^{19}$ suggests that this species may be developed into a useful product. Currently, the literature lacks further information on the chemical profiles associated the cytotoxic activities of Spondias leaves.

Thus, the purpose of this study was to examine unknown biological properties (anticancer) of S. mombin and $S$. tuberosa leaves, as well as to determine the metabolomic profiles of non-polar extracts based on gas chromatography-mass spectrometry (GC-MS) data. Also, we intend to correlate the chemical compounds identified with the cytotoxicity test results to determine the potential anticancer biomarkers. The results achieved in this study may provide new insight into the discovery and development of new drugs from agricultural inputs.

\section{Experimental}

\section{Samples, reagents, and chemicals}

Yellow mombin (S. mombin) and umbu leaves (S. tuberosa) were collected in Petrolina-PE, Brazil. Posteriorly, were dried $\left(40{ }^{\circ} \mathrm{C}\right.$ for 3 days), grounded and stored for further extraction. This project is authorized by the Genetic Heritage Management Council. Accession to genetic patrimony No. AF91C72.

The $N$-trimethylsilyl- $N$-methyl trifluoroacetamide (MSTFA), pyridine, and the homologous series of $n$-alkane $\mathrm{C}_{8}-\mathrm{C}_{30}$ were purchased from Sigma-Aldrich (St Louis, MO, USA). Dimethyl sulfoxide (DMSO) and 3-(4,5-dimethyl2-thiazol)-2,5-diphenyl-2 $H$-tetrazolium bromide (MTT) were purchased from Sigma-Aldrich (Darmstadt, Germany). Water was purified using a Milli-Q integral water purification system (Millipore, Bedford, MA, USA). The solvents used for extraction were analytical grade (ethanol (96\%) and hexane (95\%)) and were purchased from Tedia (Rio de Janeiro, RJ, Brazil).

\section{Extraction and derivatization}

The samples $(500 \mathrm{mg})$ were extracted with $4 \mathrm{~mL}$ hexane, vortexed for $1 \mathrm{~min}$ and ultrasound bath for $20 \mathrm{~min}$, centrifuged at $3000 \mathrm{rpm}$ for $10 \mathrm{~min}$, and suspended plant materials were decanted. Posteriorly, a $3 \mathrm{~mL}$ of the extract was concentrated under vacuum on a rotary evaporator. The extraction was performed in quadruplicates for S. mombin and S. tuberosa..$^{20-22}$

The derivatization of the extract was designed by the method described in the literature, where $10 \mathrm{mg}$ of dry extract were solubilized in pyridine $(200 \mu \mathrm{L})$. After, was added MSTFA $(200 \mu \mathrm{L})$, and water bath at $37^{\circ} \mathrm{C}$ for $30 \mathrm{~min} .{ }^{23}$ The extracts were then filtered and stored for $24 \mathrm{~h}$ at $4{ }^{\circ} \mathrm{C}$ prior to chromatographic analysis.

\section{Chromatographic analysis of extracts}

The chromatographic analyzes performed on the GC-MS 7890B/MSD-5977A (Agilent, California, USA) equipment were programmed in the same conditions as reported in a paper described in the literature. ${ }^{22}$ Additionally, the extracts containing the derivatized compounds were designated by standard data (National Standards and Technology - NIST). Besides, the linear retention indices (LRI) of a series of $n-\mathrm{C}_{8}-\mathrm{C}_{30}$ alkanes was used to distinguish the metabolites tentatively identified. ${ }^{24}$

\section{Biological tests}

The leaf extracts of $S$. mombin and $S$. tuberosa were performed by in vitro tests (MTT assays) against different cancer cell lines: prostate (PC3), human colon carcinoma (HCT-116), astrocytoma (SNB19), leukemia (HL60), breast (MCF-7), cervix (HeLa), and murine fibroblast (L929). The selectivity index of the metabolites for proliferation of a non-tumor cell line (L929) was used as control. Tumor cell lines were cultured according to the methodology described in the literature..$^{22}$

\section{Evaluation of cytotoxicity}

The viability of the healthy and diseased cell line was assessed by the MTT assay using doxorubicin as a positive control. ${ }^{25}$ All experimental conditions, obtaining and analyzing the half maximal inhibitory concentration $\left(\mathrm{IC}_{50}\right)$ and growth inhibition (GI, \%) were carried out as set out in literature. ${ }^{22}$ Also, to evaluate the cell-killing potential of the extracts, the following intensity scale reported in literature was used: GI, \%, high (75-100\%) and moderate (51-74\%). ${ }^{26,27}$

\section{Chemometric analysis}

The extractions were obtained in four biological replicates of $S$. mombin and $S$. tuberosa, totaling eight 
chromatograms. Thus, the chromatograms were imported and analyzed in the Origin ${ }^{\mathrm{TM}}$ program $^{28}$ for construction of matrix data. Subsequently, the matrix data obtained by this method were used for principal component analysis (PCA), and partial least squares (PLS) analyzes on Unscrambler $\mathrm{X}^{\mathrm{TM}}$ program 10.4 software. ${ }^{29}$

Decomposition of the matrix by singular value decomposition (SVD) algorithm, correction of the baseline, a step of standardization of the data (normalization) and, finally, scaling of the centered composition in the mean was performed. ${ }^{30}$ Through the PCA, important information about the similarities and differences between the sample sets was obtained, at $95 \%$ confidence level.

In order to correlate the idication of possible marker compounds based on biological tests with the species of leaves and to improve the relationship between samples and composition, regression modeling by PLS was developed using each cytotoxic activity as a categorical variable. The nonlinear iterative partial least squares (NIPALS) algorithm was used for model construction. The number of latent variables (LV) were established in accordance to the following statistical parameters: root mean square error of calibration (RMSEC), root mean square error of cross validation (RMSECV), and the respective calibration coefficient $\left(\mathrm{R}^{2}\right)$. $^{31,32}$

\section{Results and Discussion}

\section{Cytotoxicity}

Through single-concentration initial screening tests (100 $\mu \mathrm{g} \mathrm{mL}^{-1}$ ), we showed that hexane leaf extracts from $S$. tuberosa resulted in more than $70 \%$ growth inhibition (90.48 to $99.23 \%$ ) in all cell lines tested. S. mombin extracts were cytotoxic against prostate cell lines only, at an inhibition rate of $75.28 \%$ and showed low cytotoxicity to the non-tumoral cell line (L929). Table 1 describes the percentages of inhibition of cell proliferation of leaf extracts from S. mombin and S. tuberosa against the tumor cells lines HCT-116 (colon carcinoma), PC3 (prostate), HL60 (leukemia), MCF-7 (breast), SNB19 (astrocytoma), and HeLa (cervix). Data are shown as mean cell growth inhibition against the cell lines, illustrated at Figure 1.

It is known that the percentage of inhibition of cell growth is high when it is between $75 \%$ and $100 \%$, and moderate when the inhibition is between $51 \%$ and $74 \% .{ }^{22} \mathrm{In}$

Table 1. Inhibition percentage of cell growth of hexanic extracts from S. mombin and S. tuberosa leaves, determined by MTT assay after $72 \mathrm{~h}$ of incubation, at a concentration of $100 \mu \mathrm{g} \mathrm{mL}-1$

\begin{tabular}{|c|c|c|c|c|c|c|c|}
\hline \multirow[b]{2}{*}{ Species } & \multicolumn{7}{|c|}{ Inhibition of cell growth $/(\mathrm{GI} \% \pm \mathrm{SD})$} \\
\hline & $\begin{array}{c}\text { HCT-116 } \\
\text { (human colon) }\end{array}$ & $\begin{array}{c}\text { HL60 } \\
\text { (leukemia) }\end{array}$ & $\begin{array}{c}\text { PC3 } \\
\text { (prostate) }\end{array}$ & $\begin{array}{c}\text { SNB19 } \\
\text { (astrocytoma) }\end{array}$ & $\begin{array}{l}\text { MCF-7 } \\
\text { (breast) }\end{array}$ & $\begin{array}{l}\text { HeLa } \\
\text { (cervix) }\end{array}$ & $\begin{array}{c}\text { L929 } \\
\text { (fibroblast) }\end{array}$ \\
\hline S. mombin & $47.44 \pm 1.13$ & $40.09 \pm 0.23$ & $75.28 \pm 3.73$ & $20.62 \pm 4.02$ & $26.60 \pm 6.11$ & $40.68 \pm 2.76$ & $44.63 \pm 2.31$ \\
\hline S. tuberosa & $92.53 \pm 0.52$ & $90.48 \pm 0.29$ & $97.90 \pm 0.73$ & $98.41 \pm 0.42$ & $99.23 \pm 0.60$ & $93.78 \pm 1.53$ & $90.59 \pm 2.19$ \\
\hline $\mathrm{Dox}^{\mathrm{b}}, \mathrm{IC}_{50}{ }^{\mathrm{c}} /\left(\mu \mathrm{g} \mathrm{mL}^{-1}\right)$ & $\begin{array}{c}0.11 \\
(0.08-0.14)\end{array}$ & $\begin{array}{c}0.01 \\
(0.006-0.01)\end{array}$ & $\begin{array}{c}0.44 \\
(0.34-0.54)\end{array}$ & $\begin{array}{c}1.20 \\
(1.03-1.39)\end{array}$ & $\begin{array}{c}0.08 \\
(0.07-0.11)\end{array}$ & - & $\begin{array}{c}0.99 \\
(0.91-1.08)\end{array}$ \\
\hline
\end{tabular}

aExpressed as average of inhibition percentage of cell growth (GI\%, growth inhibition) from two independent experiments in triplicate \pm the standard deviation; b doxorubicin was the positive control; c drug concentration that caused 50\% inhibition of cell growth, with a $95 \%$ confidence interval.

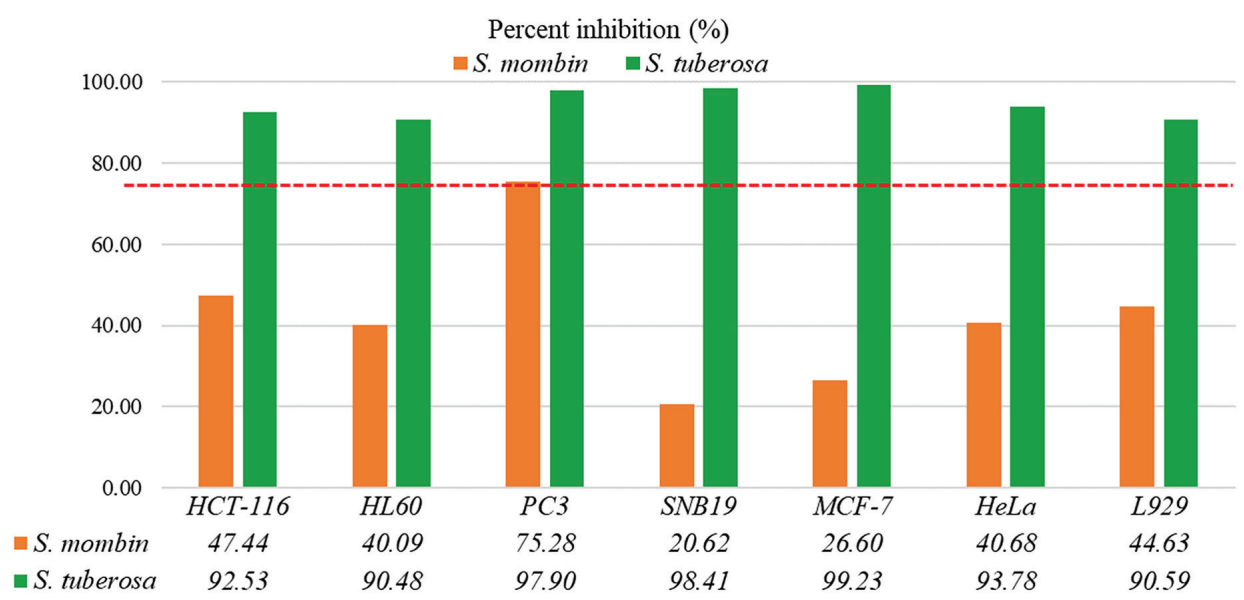

Figure 1. Inhibitory effect of hexanic extracts from leaves of S. mombin and S. tuberosa. 
this regard, $S$. tuberosa extracts presented higher activities against all tumor cell lines (HCT-116, HL60, PC3, SNB19, MCF-7, and HeLa) as compared to $S$. mombin. Conversely, S. tuberosa extracts also exhibited low selectivity between tumor and non-tumor cells (high L929 percentage).

Studies have been using the L929 cell line to verify compound selectivity, da Cruz et al..$^{33}$ and Vieira et al..$^{34}$ used the cell line to evaluate the selectivity of the quinones. Assanga et al. ${ }^{35}$ verified the growth curves of tumor and non-tumor cell lines treated with extracts of Phoradendron californicum, evaluating the selectivity index of the extracts in L929 lineage and verified that the extracts were selective to the tumoral ones. Wang et al., ${ }^{36}$ Oliveira et al. ${ }^{37}$ and Moura et al..$^{38}$ showed that their compounds were selectively toxic to tumor lineages and had lower non-tumor linear toxicity.

Compounds that exhibit about two-fold increased selectivity in tumor cells than in non-tumor cells are promising compounds for mechanism of action studies. ${ }^{39}$ The L929 cell line was studied as a normal murine cell line control by Salido et al. ${ }^{40}$ verifying that the extracts of $L$. tridentata were more selective for the tumor cells, indicating possible decreases in side effects when compared to existing drugs in the clinic.

Studies evaluated the cytotoxic activity of stem bark extracts from two species of the family Annonaceae; active extracts that resulted in more than $75 \%$ cell growth inhibition in any cell line was characterized. ${ }^{26}$ Another study examined compounds with very potent activities, which resulted in cell growth inhibition ranging from $75-100 \% .^{41}$ In this work, $S$. tuberosa showed high inhibition potential (93.78\%) against the HeLa cell line. This data supported study results reported in the literature, which showed similar activity with extracts from Salvia sahendica; these extracts resulted in $100 \%$ inhibition at a concentration of $100 \mu \mathrm{g} \mathrm{mL}^{-1}$ for the same lineage and was categorized as a highly cytotoxic species. ${ }^{42}$

Hexane extracts of $S$. tuberosa bark in human epidermoid cancer cells (HEp-2 cells) did not cause cytotoxicity at any concentration; conversely, an increase in cell number was observed at $250 \mu \mathrm{g} \mathrm{mL}{ }^{-1} .^{43}$ In this study, Spondias mombin extracts inhibited cell growth by $92.53 \%$ in HCT-116 cells, $98.41 \%$ in SNB19 cells, $99.23 \%$ in MCF-7 cells, and $90.48 \%$ in HL60 cells.

Spondias mombin leaf extracts inhibited cell growth by $75.28 \%$ in the prostate cell line. Studies revealed that the extract of this species demonstrated an $\mathrm{IC}_{50}$ value of $<5 \mu \mathrm{g} \mathrm{mL}{ }^{-1}$ against the cell line MRC-5 (lung). ${ }^{44}$ Aqueous S. mombin extracts exhibited the potential to induce genetic damage in both somatic and germ cell lines. In addition, they counteracted the effects of known mutagens or carcinogens, ${ }^{45}$ which may be responsible for the difference in their bioactivities. Therefore, Spondias mombin can be a good source of natural pesticides and antitumor agents. ${ }^{46}$

Among the compounds identified in S. tuberosa, some studies reported the presence of $\alpha$-cadinol in Pallenis spinose extracts, which inhibited proliferation of leukemic and solid tumor cells (MCF-7, HepG2, HT-1080, and Caco-2) with an $\mathrm{IC}_{50}$ in the ranges of $0.25-0.66 \mu \mathrm{g} \mathrm{mL}^{-1}$ and $0.50-2.35 \mu \mathrm{g} \mathrm{mL}{ }^{-1}$, respectively. ${ }^{47}$ Another compound identified was stearic acid, which is associated with reduced cardiovascular and cancer risks. ${ }^{48}$

Palmitic acid, present in both species, has induced senescence in hepatocellular cells and also impairs the expression of the SMARCD1 gene, which appears to be responsible for the accumulation of lipids associated with aging in the hepatic cell. ${ }^{49}$ Squalene and $\alpha$-amyrin, together with other compounds present in Wrightia pubescens extracts, were effective against HT-29 (cell line colon) with an $\mathrm{IC}_{50}$ of $1.70 \mu \mathrm{g} \mathrm{mL}^{-1} .^{50}$ The compound $\beta$-amyrin showed cytotoxic effects against HCT-116 cells, and was the most active compound in Vicia monantha subsp. monantha seed extracts $\left(\mathrm{IC}_{50}=22.61 \mu \mathrm{g} \mathrm{mL}{ }^{-1}\right) .^{51}$

Our study results demonstrated that $S$. tuberosa hexane extracts show greater cytotoxicity as compared to $S$. mombin extracts in all tested cell lines. However, $S$. tuberosa leaf extracts exhibited low selectivity between tumor and non-tumor cells. In contrast, S. mombin leaf extracts were efficient against PC3 tumor cells, and also showed high selectivity between tumor and non-tumor cells. Our results also provide evidence that plants of this genus are rich sources of active metabolites showing cytotoxic activities. As these extracts show potent inhibitory effects on cell growth, future studies should focus on studying the possible molecular mechanisms of cytotoxicity.

\section{Metabolic profile of S. mombin and S. tuberosa}

An overall of 23 metabolites from S. mombin and S. tuberosa leaf extracts were characterized. Figure 2 illustrates the compounds identified in chromatograms from each extract; Table 2 describes the respective retention time, retention index, percentage of match, and representative ions $(\mathrm{m} / \mathrm{z})$ of the isolated compounds; these were found to be mainly organic acids (such as esters, carboxylic acids and fatty acid) and lipophilic vitamins. As expected, the profiles of $S$. mombin and $S$. tuberosa leaf extracts exhibited many similarities, since they belong to the same genus. However, differences in the levels of some metabolites were observed (Figure 2). 
Table 2. Compounds identified in hexane extracts from S. mombin and S. tuberosa leaves

\begin{tabular}{|c|c|c|c|c|c|c|c|c|}
\hline Compound name & $t_{R}{ }^{a} / \min$ & $R I_{\exp }^{b}$ & $\mathrm{RI}_{\mathrm{lit}}^{\mathrm{c}}$ & Match $^{\mathrm{d}}$ & R. match $^{\mathrm{d}}$ & $\begin{array}{c}\text { Representative } \\
\text { fragment ions }(\mathrm{m} / \mathrm{z})\end{array}$ & S. mombin & S. tuberosa \\
\hline$\alpha$-Cadinol & 15.89 & 1656 & 1652 & 875 & 926 & $\begin{array}{c}43,95\left(\mathrm{BP}^{\mathrm{e}}\right), 121 \\
161,204,222\left(\mathrm{M}^{+\bullet}\right)\end{array}$ & & + \\
\hline Dodecanoic acid ${ }^{g}$ & 23.26 & 1881 & 1881 & 817 & 846 & $\begin{array}{c}73,75,95,129 \\
257(\mathrm{BP})\end{array}$ & + & \\
\hline Myristic acid ${ }^{g}$ & 29.46 & 2080 & 2080 & 947 & 948 & $\begin{array}{c}73,75,117,129 \\
285(\mathrm{BP}), 342\left(\mathrm{M}^{+*}\right)\end{array}$ & + & + \\
\hline Malic acidg & 30.24 & 2107 & 2095 & 759 & 902 & $\begin{array}{c}73 \text { (BP), } 115,147 \\
287,419\end{array}$ & + & \\
\hline Pentadecanoic acid ${ }^{g}$ & 32.39 & 2181 & 2181 & 876 & 893 & $\begin{array}{c}73,75,117,129 \\
299(\mathrm{BP}), 356\left(\mathrm{M}^{+*}\right)\end{array}$ & + & \\
\hline cis-9-Hexadecenoic acidg & 34.97 & 2272 & 2269 & 812 & 813 & $\begin{array}{c}73,75,129 \\
311(\mathrm{BP}), 353\end{array}$ & + & + \\
\hline Palmitic acidg & 35.36 & 2287 & 2281 & 948 & 948 & $\begin{array}{c}73,75,117,129 \\
313(\mathrm{BP}), 370\left(\mathrm{M}^{+*}\right)\end{array}$ & + & + \\
\hline Margaric acid & 37.98 & 2384 & 2388 & 801 & 901 & $\begin{array}{c}73,75,117,129 \\
327(\mathrm{BP}), 384\left(\mathrm{M}^{+*}\right)\end{array}$ & + & \\
\hline Linoleic acid ${ }^{\mathrm{g}}$ & 39.85 & 2455 & 2462 & 945 & 945 & $\begin{array}{c}73,75,129 \\
337(\mathrm{BP}), 379\end{array}$ & + & + \\
\hline $9,12,15$-Octadecatrienoic acid & 40.07 & 2467 & 2470 & 953 & 956 & $\begin{array}{c}73,75,95,129 \\
335(\mathrm{BP}), 392\left(\mathrm{M}^{+*}\right)\end{array}$ & + & + \\
\hline Stearic acid ${ }^{\mathrm{g}}$ & 40.64 & 2486 & 2483 & 810 & 910 & $\begin{array}{c}73,75,117,129 \\
341(\mathrm{BP}), 398\left(\mathrm{M}^{+*}\right)\end{array}$ & & + \\
\hline Nonadecanoic acid ${ }^{g}$ & 43.14 & 2585 & 2584 & 768 & 906 & $\begin{array}{c}73,75,117,129 \\
355(\mathrm{BP}), 412\left(\mathrm{M}^{+*}\right)\end{array}$ & + & \\
\hline Citric acid ${ }^{g}$ & 43.96 & 2618 & 2590 & 820 & 837 & $\begin{array}{c}73 \text { (BP), 147, 357 } \\
431,459,591\end{array}$ & + & \\
\hline Squalene & 48.94 & 2830 & 2836 & 963 & 966 & $\begin{array}{c}69 \text { (BP), } 81,95 \\
121,137\end{array}$ & + & + \\
\hline Behenic acid ${ }^{g}$ & 50.27 & 2889 & 2910 & 926 & 936 & $\begin{array}{c}73,75,117,129, \\
397(\mathrm{BP})\end{array}$ & + & \\
\hline Tricosanoic acidg & 52.48 & 2990 & 2985 & 856 & 890 & $\begin{array}{c}73,75,117,129 \\
411(\mathrm{BP})\end{array}$ & + & + \\
\hline Tetracosanoic acid ${ }^{g}$ & 54.65 & $>3000$ & 3088 & 909 & 927 & $\begin{array}{c}73,75,117,129 \\
425(\mathrm{BP}), 482\left(\mathrm{M}^{+*}\right)\end{array}$ & + & + \\
\hline$\alpha$-Tocopherolquinone & 55.70 & $>3000$ & - & 709 & 774 & $\begin{array}{c}150,165,178,221 \\
(\mathrm{BP}), 430,446\left(\mathrm{M}^{+*}\right)\end{array}$ & + & + \\
\hline$\delta$-Tocopherol ${ }^{\mathrm{g}}$ & 55.92 & $>3000$ & 3153 & 714 & 715 & $\begin{array}{c}73,195,251,291 \\
516\left(\mathrm{BP}^{+} \mathrm{M}^{+*}\right)\end{array}$ & + & \\
\hline$\gamma$-Tocopherol ${ }^{g}$ & 58.28 & $>3000$ & 3269 & 615 & 631 & $\begin{array}{c}73,209,265,305 \\
530\left(\mathrm{BP}, \mathrm{M}^{+*}\right)\end{array}$ & + & \\
\hline$\beta$-Amyrin & 59.30 & $>3000$ & 3314 & 852 & 904 & $\begin{array}{c}95,203,218(\mathrm{BP}) \\
426\left(\mathrm{M}^{+*}\right)\end{array}$ & & + \\
\hline$\alpha$-Amyrin & 60.31 & $>3000$ & 3355 & 863 & 889 & $\begin{array}{c}95,135,189,203 \\
218(\mathrm{BP}), 426\left(\mathrm{M}^{+*}\right)\end{array}$ & + & + \\
\hline$\alpha$-Tocopherol ${ }^{\mathrm{g}}$ & 62.79 & $>3000$ & 3419 & 736 & 774 & $\begin{array}{l}73,207,221 \\
544\left(\mathrm{BP}, \mathrm{M}^{+*}\right)\end{array}$ & + & + \\
\hline
\end{tabular}

a Retention time; bexperimental retention index; ' retention index from literature; ${ }^{\mathrm{d}}$ reverse match value high: all masses in the library spectrum are present in the sample spectrum and match value low: the sample spectrum has more mass signals than the library spectrum; ${ }^{\mathrm{e}}$ base peak; ${ }^{\mathrm{f}}$ molecular ion; ${ }^{\mathrm{g}} \mathrm{compounds}$ as trimethylsilyl (TMS) derivatives.

\section{Chemometric evaluation}

Due to the complexity and high dimensionality of the dataset obtained by GC-MS (total of 23 compounds $x$ 8 chromatograms $=184$ variables , , exploratory chemometric analysis by principal component analysis (PCA) was developed to evaluate the variability in the organic composition of S. mombin and S. tuberosa leaves. Figure 3 illustrates the results; bidimensional scores $(\mathrm{PC} 1 \times \mathrm{PC} 2)$ are shown on the top left (Figure 3a), influence plots of extracts 


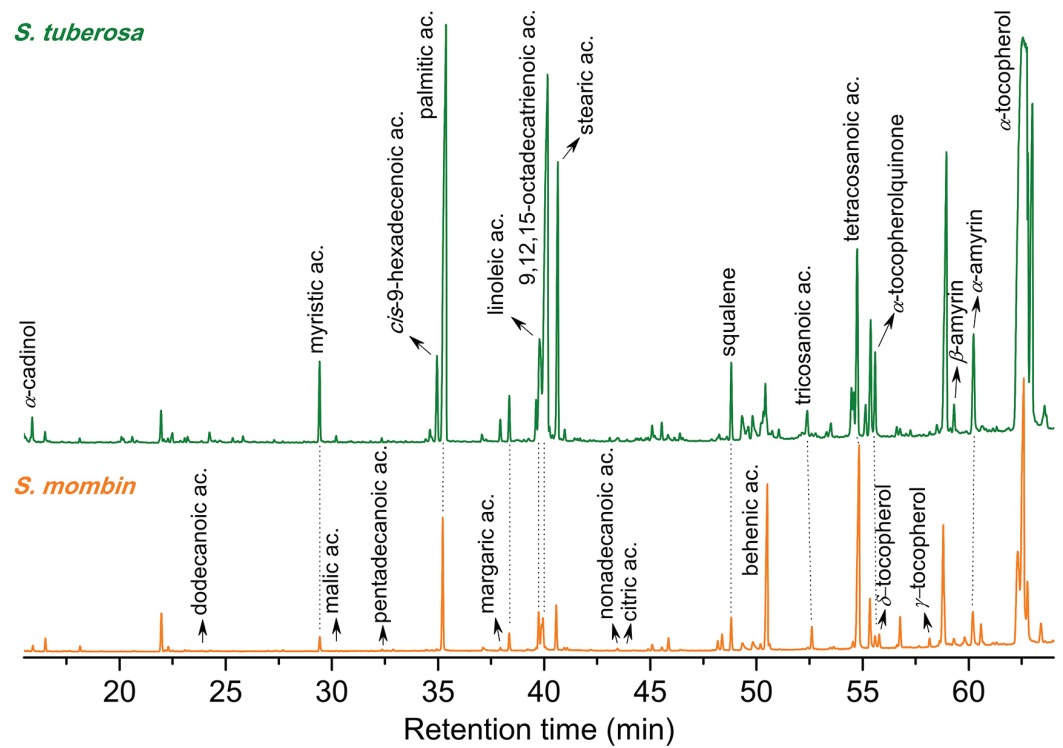

Figure 2. Chromatograms (same scale) obtained by GC-MS of the hexane extracts from Spondias leaves: green denotes $S$. tuberosa and oranges denotes S. mombin.

based on Hotelling's $\mathrm{T}^{2}$ versus F-residuals modeling of $\mathrm{PC} 1$ are shown on the top right (Figure 3b), and the relevant loadings for samples are shown on the bottom (Figure 3c).

According to the scores plot (Figure 3a), PC1 retained almost all model variability of extract samples, at $98.5 \%$ total variance. In addition, compositions of $S$. tuberosa leaf extracts were more homogeneous as compared with those of
S. mombin (Figure 3b), which supports its high influence on the model. At large, the respective loadings (PC1) represented the topmost amounts of squalene, behenic acid, tricosanoic acid, tetracosanoic acid, and $\delta$-tocopherol $S$. mombin extracts. In contrast, S. tuberosa extracts presented higher levels of myristic acid, cis-9-hexadecenoic acid, palmitic acid, $\alpha$-tocopherol, stearic acid, linoleic acid and 9,12,15-octadecatrienoic acid.
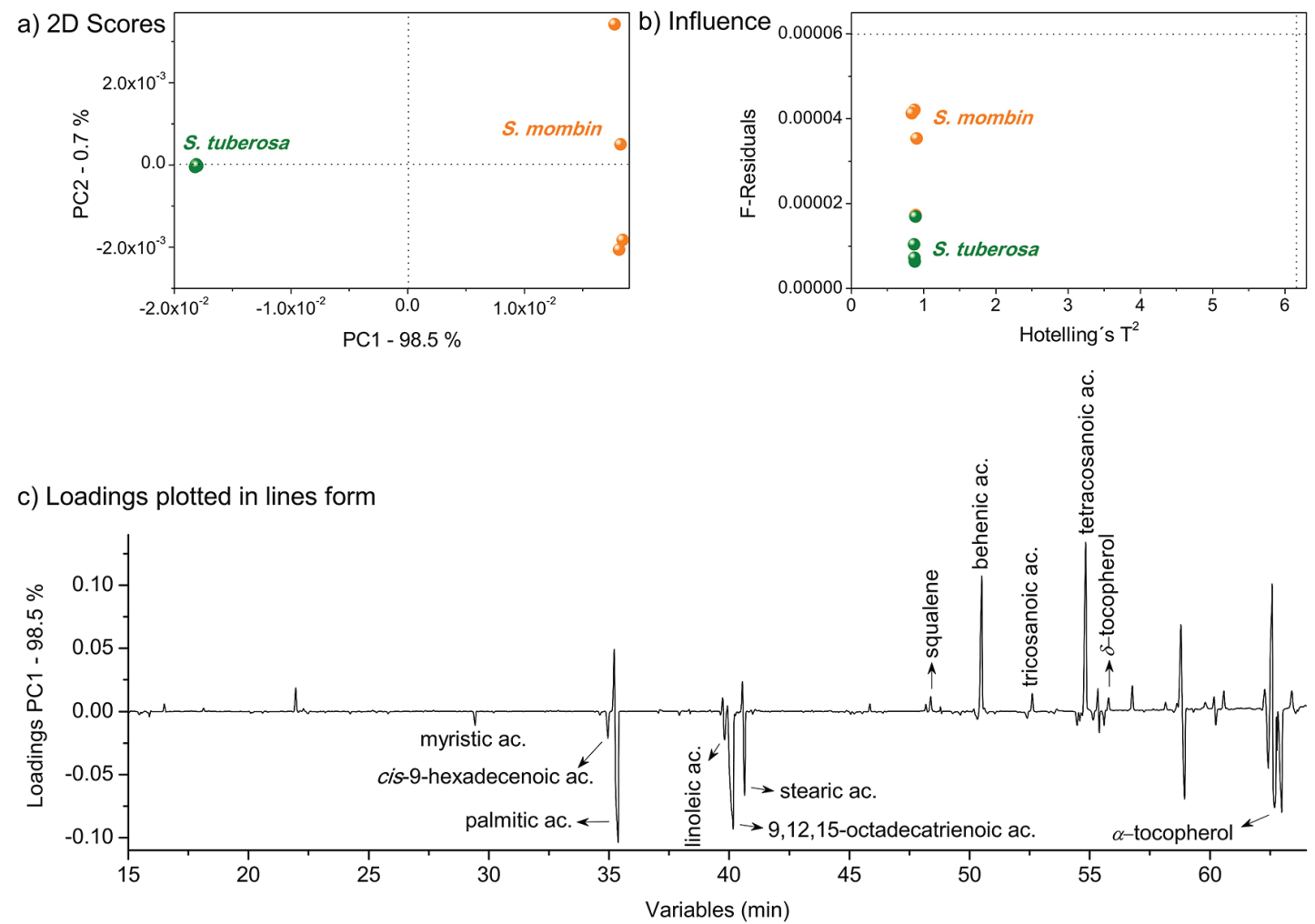

Figure 3. Chemometrics analysis: (a) bidimensional scores coordinate system $(\mathrm{PC} 1 \times \mathrm{PC} 2)$ from $S$. mombin and $S$. tuberosa leaf extracts; (b) influence plot from Hotelling's $\mathrm{T}^{2} \times F$-residuals; (c) line forms of relevant loadings. 
Unsupervised chemometric evaluation of PCA was carried out to examine the phytochemical profiles of S. mombin and S. tuberosa; results indicated high variability between species. Therefore, due to the elevate amount of information, a heat map analysis was developed and shown in Figure 4 as a 3D dendrogram (samples $\times$ retention times $\times$ signals intensity). The analysis highlighted the difference between $S$. mombin and $S$. tuberosa samples, which is attributed to higher levels of various compounds at $29.46 \mathrm{~min}$ (myristic acid), $34.97 \mathrm{~min}$ (cis-9-hexadecenoic acid), $35.36 \mathrm{~min}$ (palmitic acid), $39.85 \mathrm{~min}$ (linoleic acid), $40.07 \mathrm{~min}$ (9,12,15-octadecatrienoic acid), $40.64 \mathrm{~min}$ (stearic acid), and $48.94 \mathrm{~min}$ (squalene) in S. tuberosa as compared with those in $S$. mombin samples. On the other hand, several compounds were elevated at $50.27 \mathrm{~min}$ (behenic acid), $52.48 \mathrm{~min}$ (tricosanoic acid), $54.65 \mathrm{~min}$
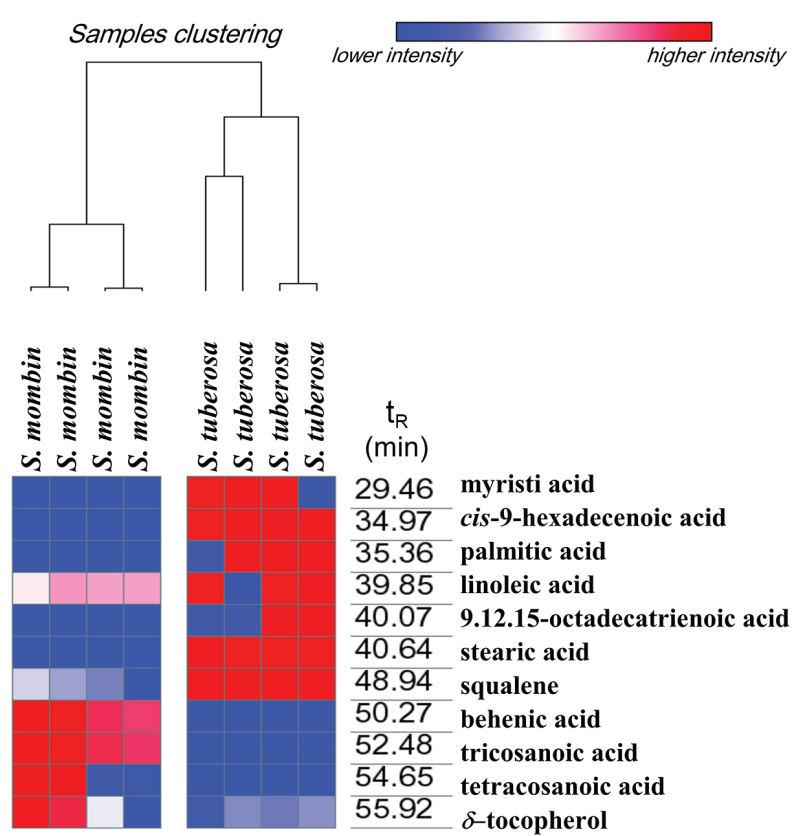

Figure 4. Heat map showing the variability in the amounts of metabolites between $S$. mombin and S. tuberosa. (tetracosanoic acid), and $55.92 \mathrm{~min}$ ( $\delta$-tocopherol) in S. mombin samples.

Based on results from the PCA and cytotoxic activities described in Table 1, a regression model by PLS was developed using each cytotoxic activity as a categorical variable to define the association between samples, cytotoxic activities, and marker compounds. The statistical parameters used to achieve model qualities are described in Table 3.

The high explained variance in the PC1 axis, the calibration coefficient $\left(\mathrm{R}^{2}\right)$, and the similarity criteria for both calibration and cross validation presented elevate classification quality in all models. Furthermore, proximity between the values prevented clear indication of the most appropriate regression models. However, the prostate activity (PC3) model showed the lowest calibration and validation errors, which indicated that this model may appropriately describe the relationship between extract composition and cytotoxic activity.

High cytotoxic activities were showcased by $S$. tuberosa extracts against both tumor and non-tumor cell lines; S. mombin extracts were only cytotoxic toward prostate tumor cells, which suggested that leaves extract of S. mombin may be more relevant for our study purposes.

The metabolites myristic acid, cis-9-hexadecenoic acid, palmitic acid, linoleic acid, 9,12,15-octadecatrienoic acid, and stearic compounds may be associated with elevated activity against the tumor cells lines human colon, prostate, astrocytoma, breast, cervix, and the non-tumor cells line L929 (Figure 3). A previous study showed that palmitic acid and 9,12-octadecadienoate in hexane extracts from pineapple leaves are markers for cytotoxic activity against the human colon, prostate, astrocytoma, breast, and cervix cell lines. In addition, margaric acid, stigmasterol, cis-11-eicosenoic acid, and $\delta$-tocopherol were also highly cytotoxic against the leukemia. ${ }^{22}$

On the other hand, S. mombin leaf extracts exerted inhibitory effects on PC3 tumor cell proliferation and

Table 3. Multivariate regression modeling using PLS for each tumor line tested

\begin{tabular}{|c|c|c|c|c|c|c|}
\hline Model & $\mathrm{LV}^{\mathrm{a}} / \%$ & $\mathrm{R}^{2} \mathrm{cal}^{\mathrm{b}}$ & RMSEC $^{\mathrm{c}}$ & $\mathrm{R}^{2} \mathrm{val}^{\mathrm{d}}$ & RMSECV $^{\mathrm{e}}$ & RMSEC / RMSECV \\
\hline Human colon & 99.99 & 0.999 & 0.234 & 0.999 & 0.347 & 0.67 \\
\hline Leukemia & 99.99 & 0.999 & 0.261 & 0.999 & 0.388 & 0.67 \\
\hline Prostate & 99.99 & 0.999 & 0.117 & 0.999 & 0.174 & 0.67 \\
\hline Astrocytoma & 99.99 & 0.999 & 0.403 & 0.999 & 0.598 & 0.67 \\
\hline Breast & 99.99 & 0.999 & 0.376 & 0.999 & 0.559 & 0.67 \\
\hline Cervix & 99.99 & 0.999 & 0.275 & 0.999 & 0.408 & 0.67 \\
\hline L929 & 99.99 & 0.999 & 0.238 & 0.999 & 0.354 & 0.67 \\
\hline
\end{tabular}

${ }^{\mathrm{a}}$ Total variance percent in $\mathbf{X}$ matrix refer to one latent variable (LV); ${ }^{\text {c}}$ calibration coefficient between the real value and the value predicted during the calibration; ' root mean square error of calibration; ${ }^{\mathrm{d}}$ calibration coefficient between the real value and the value predicted during the validation; ${ }^{\mathrm{e}}$ root mean square error of cross validation; ${ }^{\mathrm{f}}$ similarity criterion. 
demonstrated selectivity between tumor and non-tumor cells. Chemical markers that may be associated with cytotoxic activity against prostate tumor cells (PC3) were suggested to be squalene, tricosanoic acid, $\delta$-tocopherol, and mainly the acids as well as behenic and tetracosanoic acids (Figure 3).

Behenic (C24:0) and tetracosanoic (C24:0) acids are important fatty acids. In general, lipids are able to modulate the viability of tumor cells. ${ }^{52-54}$ However, there is no direct evidence that suggests behenic and tetracosanoic acids are potential anti-cancer prostate agents.

Isoprenoid squalene was suggested to complement anticancer therapies. ${ }^{55}$ It is considered to be a potent chemopreventative and chemotherapeutic agent, and is able to inhibit tumor growth in ovarian, lung, skin, lung, breast, and colon cancers. ${ }^{56}$

Squalene is a lipid predecessor of (3ß)-cholest-5-en3-ol production, which allows the bio-conjugates formed naturally to be able to self-modulate as nanoparticles to become better their biological activity. ${ }^{57}$ It has been reported that this lipid acts as a drug carrier by chemically linking with drugs to improve certain physicochemical properties. For example, administration of squalene-doxorubicin nanohybrids resulted in higher reduction of pancreatic tumors when compared with free doxorubicin. (95\% versus $29 \%) .{ }^{58}$ Therefore, squalenebased nanoparticles have been considered to be promising candidates for anti-cancer drugs. ${ }^{59-61}$ In the nutritional context, virgin olive oil is an important source of squalene. ${ }^{62}$ Consumption of olive oil has been correlated with lower risk of tumor development in various cancer types. ${ }^{56,63,64}$

We found three vitamin E isoforms, $\alpha, \gamma$ and $\delta$-tocopherol in $S$. tuberosa and S. mombin. Specifically, $\alpha$-tocopherol was found in $S$. tuberosa hexanic extracts, while the other two isoforms were found only in S. mombin extracts.

Recently, preclinical investigations into vitamin $\mathrm{E}$ isoforms revealed that aside from the non-alpha-tocopherol form, all others show promising anticancer effects. ${ }^{65}$ Tocopherols, particularly the $\gamma$ and $\delta$ homologs, have been shown to prevent the development of various kind of tumor, including prostate. ${ }^{65-67}$

Studies that examined the synergistic effects of vitamin E isoforms against human androgen-dependent prostate cancer cells ( $\mathrm{LNCaP}$ ) indicated that the combination of $\delta$-tocopherol and $\gamma$-tocotrienol significantly inhibits prostate cancer cell growth. ${ }^{68}$

In contrast, a racemic tocopherol study in two prostate cancer cell lines (LNCaP and PC3) indicated that neither $R, R, R$ - $\alpha$-tocopherol nor $R, R, R$ - $\gamma$-tocopherol exhibits inhibitory effects on cell development and apoptotic cell death. ${ }^{69}$
Thereby, experimental evidence and literature data strongly supports the possibility of chemical markers of $S$. tuberosa and $S$. mombin being potential agents against tumor cells. In view of various reports regarding the potential of vitamin $\mathrm{E}$ isoforms, our experimental results suggested vitamin $\mathrm{E}$ isoforms act through synergistic effects.

Based on data presented to date, metabolites may exert potential cytotoxic activities in prostate cancer cells (PC3) and act as biomarkers. Among these, we propose that vitamin $\mathrm{E}$ isoforms ( $\delta$-tocopherol) and squalene are the major contributors for our experimental results.

\section{Conclusions}

In the chromatographic analyzes by GC-MS, twenty-three different metabolites were detected in hexane extracts from $S$. mombin and $S$. tuberosa. Using chemometric tools, we established chemical markers that distinguished between $S$. mombin (squalene, tricosanoic acid, $\delta$-tocopherol, behenic acid and tetracosanoic acid) and $S$. tuberosa (myristic acid, cis-9-hexadecenoic acid, palmitic acid, 9,12,15-octadecatrienoic acid, linoleic acid, and stearic acid) leaf extracts, which may be associated with the observed differences in cytotoxic activity.

In addition, we verify that hexane extracts from $S$. tuberosa exhibited higher activities against all tumor cell lines as compared with those from $S$. mombin. Within the ambit, $S$. tuberosa showed potent cytotoxic activity against six tumor lines and demonstrated 90.48-99.23\% inhibition against cell growth. However, hexane extract from $S$. tuberosa leaves showed low selectivity between tumor and non-tumor lines, and therefore are not ideal candidates for therapeutics. On the other hand, hexanic extracts from $S$. mombin exhibited lower proliferative inhibition (20.62-75.28\%). Nevertheless, cell growth of prostate cell lines was inhibited by $75.28 \%$. More importantly, $S$. mombin demonstrated high selectivity between tumor and non-tumor cells and is therefore considered a promising phytotherapeutic candidate against cancer.

The results of this work demonstrate that hexane extracts of $S$. tuberosa present greater cytotoxic activity than $S$. mombin in all tested cell lines. Since existing literature lacks data on cytotoxicity of these two species, our work provides valuable information on the medicinal properties of these species. Our data suggest that $S$. tuberosa and $S$. mombin leaves are potentially important supplements because of their nutritional content and due to their ability to reduce the risk of cancer. In view of this, the above data suggest that these plant extracts may possibly be potential therapeutic agents. 


\section{Acknowledgments}

This study was financed in part by the Coordenação de Aperfeiçoamento de Pessoal de Nível Superior - Brasil (CAPES) - Finance Code 001. The authors gratefully acknowledge financial support from the CNPq, National Council for Scientific and Technological Development (303791/2016-0), INCT BioNat, National Institute of Science and Technology (grant No. 465637/2014-0). We would also like to thank Embrapa (SEG 03.14.01.012.00.00).

\section{References}

1. Sampaio, T. I. S.; Melo, N. C.; Paiva, B. T. F.; Aleluia, G. A. S.; Silva Neto, F. L. P.; Silva, H. R.; Keita, H.; Cruz, R. A. S.; Sánchez-Ortiz, B. L.; Pineda-Peña, E. A.; Balderas, J. L.; Navarrete, A.; Carvalho, J. C. T.; J. Ethnopharmacol. 2018, 224, 563.

2. Mattietto, R. A.; Matta, V. M. In Postharvest Biology and Technology of Tropical and Subtropical Fruits; Yahia, E. M., ed.; Woodhead Publishing: Oxford, 2011, ch. 15.

3. Neiens, S. D.; Geiblitz, S. M.; Steinhaus, M.; Eur. Food Res. Technol. 2017, 243, 1073.

4. Teai, T.; Claude-Lafontaine, A.; Schippa, C.; Cozzolino, F.; J. Essent. Oil Res. 2005, 17, 368.

5. Lima, M. A. C.; Silva, S. M.; Oliveira, V. R. In Exotic Fruits; Rodrigues, S.; Silva, E. O.; de Brito, E. S., eds.; Elsevier: Amsterdam, 2018, p. 427.

6. Neto, E. M. de F. L.; Peroni, N.; Maranhão, C. M. C.; Maciel, M. I. S.; de Albuquerque, U. P.; Environ. Monit. Assess. 2012, $184,4489$.

7. Sameh, S.; Al-Sayed, E.; Labib, R. M.; Singab, A. N.; J. Evidence-Based Complementary Altern. Med. 2018, 2018, 5382904.

8. Tiburski, J. H.; Rosenthal, A.; Deliza, R.; Godoy, R. L. O.; Pacheco, S.; Food Res. Int. 2011, 44, 2326.

9. Gouvêa, R. F.; Ribeiro, L. O.; Souza, E. F.; Penha, E. M.; Matta, V. M.; Freitas, S. P.; J. Food Sci. Technol. 2017, 54, 2176.

10. Silva, B. M.; Rossi, A. A. B.; Tiago, A. V.; Schmitt, K. F. M.; Dardengo, J. F. E.; Souza, S. A. M.; Genet. Mol. Res. 2017, 16, gmr16018946.

11. Maldonado-Astudillo, Y. I.; Alia-Tejacal, I.; Núñez-Colín, C. A.; Jiménez-Hernández, J.; Pelayo-Zaldívar, C.; López-Martínez, V.; Andrade-Rodríguez, M.; Bautista-Baños, S.; Valle-Guadarrama, S.; Sci. Hortic. 2014, 174, 193.

12. Daniyal, M.; Akram, M.; J. Chin. Med. Assoc. 2015, 78, 382.

13. Offiah, V. N.; Anyanwu, I. I.; J. Ethnopharmacol. 1989, 26, 317.

14. Uchendu, C. N.; Isek, T.; Afr. Health Sci. 2008, 8, 163.

15. Barbosa, H. de M.; Amaral, D.; Nascimento, J. N.; Machado, D. C.; Araújo, T. S. A.; Albuquerque, U. P.; Almeida, J. R. G. S.;
Rolim, L. A.; Lopes, N. P.; Gomes, D. A.; Lira, E. C.; J. Ethnopharmacol. 2018, 227, 248.

16. Santos, P. A.; Rezende, L. C.; de Oliveira, J. C. S.; David, J. M.; David, J. P.; Int. J. Fruit Sci. 2018, DOI: 10.1080/15538362.2018.1502721.

17. Zeraik, M. L.; Queiroz, E. F.; Marcourt, L.; Ciclet, O.; CastroGamboa, I.; Silva, D. H. S.; Cuendet, M.; Bolzani, V. S.; Wolfender, J.-L.; J. Funct. Foods 2016, 21, 396.

18. Araújo, A. R. S.; Morais, S. M.; Marques, M. M.; Oliveira, D. F.; Barros, C. C.; Almeida, R. R.; Gusmão, Í.; Vieira, P.; Izabel, M.; Guedes, F.; Pharm. Biol. 2012, 6, 740.

19. Tomás-Barberán, F. A.; Clifford, M. N.; J. Sci. Food Agric. 2000, 80, 1024.

20. Nehme, C. J.; de Moraes, P. L. R.; Tininis, A. G.; Cavalheiro, A. J.; Biochem. Syst. Ecol. 2008, 36, 602.

21. Chagas-Paula, D. A.; Zhang, T.; Da Costa, F. B.; Edrada-Ebel, R. A.; Metabolites 2015, 5, 404.

22. Guedes, J. A. C.; Alves Filho, E. G.; Rodrigues, T. H. S.; Silva, M. F. S.; Souza, F. V. D.; Silva, L. M. A.; Alves, R. E.; Canuto, K. M.; Brito, E. S.; Pessoa, C. Ó.; Nascimento, R. F.; Zocolo, G. J.; Ind. Crops Prod. 2018, 124, 466.

23. Silva, J. G. A.; Silva, A. A.; Coutinho, I. D.; Pessoa, C. O.; Cavalheiro, A. J.; Silva, M. G. V.; J. Braz. Chem. Soc. 2016, 27, 1872 .

24. van Den Dool, H.; Kratz, P. D.; J. Chromatogr. A 1963, 11, 463.

25. Mosmann, T.; J. Immunol. Methods 1983, 65, 55.

26. Pinheiro, S.; Rabelo, S. V.; Oliveira, A. P.; Guimarães, A. L.; Moraes-Filho, M. O.; Pinheiro, M.; Pessoa, C. Ó.; Sílvia, A.; Carneiro, S.; Guedes, R.; Trop. J. Pharm. Res. 2016, 15, 793.

27. ISO Guide 10993-5: Biological Evaluation of Medical Devices - Part 5: Tests For In Vitro Cytotoxicity, ISO: Geneva, 2009.

28. OriginPro 9.0.0; OriginLab Corporation: USA, Northampton, 2013.

29. The Unscrambler X 10.4; CAMO Software AS: Norway, Oslo, 2016.

30 Freitas, J. V. B.; Alves Filho, E. G.; Silva, L. M. A.; Zocolo, G. J.; de Brito, E. S.; Gramosa, N. V.; Talanta 2018, 180, 329.

31. Beebe, K. R.; Pell, R. J.; Seasholtz, M. B.; Chemometrics: A Practical Guide; $1^{\text {st }}$ ed.; Wiley-Interscience: New York, 1998.

32. Hotelling, H.; J. Educ. Psychol. 1933, 24, 417.

33. da Cruz, E. H. G.; Silvers, M. A.; Jardim, G. A. M.; Resende, J. M.; Cavalcanti, B. C.; Bomfim, I. S.; Pessoa, C.; de Simone, C. A.; Botteselle, G. V.; Braga, A. L.; Nair, D. K.; Namboothiri, I. N. N.; Boothman, D. A.; da Silva Jr., E. N.; Eur. J. Med. Chem. 2016, 122, 1 .

34. Vieira, A. A.; Brandão, I. R.; Valença, W. O.; De Simone, C. A.; Cavalcanti, B. C.; Pessoa, C.; Carneiro, T. R.; Braga, A. L.; Da Silva, E. N.; Eur. J. Med. Chem. 2015, 101, 254.

35. Assanga, S. B. I.; Gil-Salido, A. A.; Luján, L. M. L.; Rosas-Durazo, A.; Acosta-Silva, A. L.; Rivera-Castañeda, E. G.; Rubio-Pino, J. L.; Int. J. Biotechnol. Mol. Biol. Res. 2013, 4, 60. 
36. Wang, L.; Luo, X.; Li, C.; Huang, Y.; Xu, P.; Lloyd-Davies, L. H.; Delplancke, T.; Peng, C.; Gao, R.; Qi, H.; Tong, C.; Baker, P.; Oxid. Med. Cell. Longevity 2017, 2017, 3481710.

37. Oliveira, A. P.; Guimarães, A. L.; Pacheco, A. G. M.; Araújo, C. S.; Júnior, R. G. O.; Lavor, É. M.; Silva, M. G.; Araújo, E. C. C.; Mendes, R. L.; Rolim, L. A.; Costa, M. P.; Farias, H. C. L.; Pessoa, C. D. O.; Lopes, N. P.; Marques, L. M. M.; Almeida, J. R. G. S.; Quim. Nova 2016, 39, 32.

38. Moura, A. F.; Lima, K. S. B.; Sousa, T. S.; Marinho-Filho, J. D. B.; Pessoa, C.; Silveira, E. R.; Pessoa, O. D. L.; CostaLotufo, L. V.; Moraes, M. O.; Araújo, A. J.; Toxicol. In Vitro 2018, 47, 129.

39. Rodrigues, C. A.; dos Santos, P. F.; da Costa, M. O. L.; Pavani, T. F. A.; Xander, P.; Geraldo, M. M.; Mengarda, A.; de Moraes, J.; Rando, D. G. G.; J. Venom. Anim. Toxins Incl. Trop. Dis. 2018, 24, 1 .

40. Salido, A. A. G.; Assanga, S. B. I.; Luján, L. M. L.; Ángulo, D. F.; Espinoza, C. L. L.; Silva, A. L. A.; Rubio, J. L.; Int. J. Sci. 2016, 5, 63 .

41. Macêdo, L. A. R. O.; Júnior, R. G. O.; Souza, G. R.; Oliveira, A. P.; Lavor, É. M.; Silva, M. G.; Pacheco, A. G. M.; Menezes, I. R. A.; Coutinho, H. D. M.; Pessoa, C. Ó.; Costa, M. P.; Almeida, J. R. G. S.; Biotechnol. Biotechnol. Equip. 2018, 32, 506.

42. Moradi-Afrapoli, F.; Shokrzadeh, M.; Barzegar, F.; Gorji-Bahri, G.; Rev. Bras. Farmacogn. 2018, 28, 27.

43. Barbosa, H. M.; Nascimento, J. N.; Araújo, T. A. S.; Duarte, F. S.; Albuquerque, U. P.; Vieira, J. R. C.; Santana, E. R. B.; Yara, R.; Lima, C. S. A.; Gomes, D. A.; Lira, E. C.; An. Acad. Bras. Cienc. 2016, 88, 1993.

44. Traore, M. S.; Diane, S.; Diallo, M. S. T.; Balde, E. S.; Balde, M. A.; Camara, A.; Diallo, A.; Keita, A.; Cos, P.; Maes, L.; Pieters, L.; Balde, A. M.; Planta Med. 2014, 80, 1340.

45. Oyeyemi, I. T.; Yekeen, O. M.; Odusina, P. O.; Ologun, T. M.; Interdiscip. Toxicol. 2015, 8, 184.

46. Oladimeji, A. O.; Aliyu, M. B.; Ogundajo, A. L.; Babatunde, O.; Adeniran, O. I.; Balogun, O. S.; Pharm. Biol. 2016, 54, 2674.

47. Al-Qudah, M. A.; Saleh, A. M.; Alhawsawi, N. L.; Al-Jaber, H. I.; Rizvi, S. A.; Afifi, F. U.; Chem. Biodivers. 2017, 14, 8.

48. Senyilmaz-Tiebe, D.; Pfaff, D. H.; Virtue, S.; Schwarz, K. V.; Fleming, T.; Altamura, S.; Muckenthaler, M. U.; Okun, J. G.; Vidal-Puig, A.; Nawroth, P.; Teleman, A. A.; Nat. Commun. 2018, 9, 3129.

49. Harada, G.; Onoue, S.; Inoue, C.; Hanada, S.; Katakura, Y.; Cytotechnology 2018, 70, 6.

50. Reyes, M. M. D. L.; Oyong, G. G.; Ng, V. A. S.; Shen, C. C.; Ragasa, C. Y.; Pharmacogn. Res. 2018, 10, 9.
51. El-Halawany, A. M.; Osman, S. M.; Abdallah, H. M.; Nat. Prod. Res. 2018, 12, 1783

52. Kaplan, M.; Koparan, M.; Sari, A.; Ozturk, S.; Kaplan, S. K.; Erol, F. S.; Can. J. Neurol. Sci. 2013, 40, 854.

53. Murray, M.; Hraiki, A.; Bebawy, M.; Pazderka, C.; Rawling, T.; Pharmacol. Ther. 2015, 150, 109.

54. Poulose, N.; Amoroso, F.; Steele, R. E.; Singh, R.; Ong, C. W.; Mills, I. G.; Nat. Genet. 2018, 50, 169.

55. Tatewaki, N.; Konishi, T.; Nakajima, Y.; Nishida, M.; Saito, M.; Eitsuka, T.; Sakamaki, T.; Ikekawa, N.; Nishida, H.; PLoS One 2016, 11, e0147570.

56. Lozano-Grande, M. A.; Gorinstein, S.; Espitia-Rangel, E.; Dávila-Ortiz, G.; Martínez-Ayala, A. L.; Int. J. Agron. 2018, 2018, 1829160.

57. Peramo, A.; Mura, S.; Yesylevskyy, S. O.; Cardey, B.; Sobot, D.; Denis, S.; Ramseyer, C.; Desmaële, D.; Couvreur, P.; C. R. Chim. 2018, 10, 974.

58. Wicki, A.; Witzigmann, D.; Balasubramanian, V.; Huwyler, J.; J. Controlled Release 2015, 200, 138.

59. Kotelevets, L.; Chastre, E.; Caron, J.; Mougin, J.; Bastian, G.; Pineau, A.; Walker, F.; Lehy, T.; Desmaële, D.; Couvreur, P.; Cancer Res. 2017, 77, 2964.

60. Bui, D. T.; Nicolas, J.; Maksimenko, A.; Desmaële, D.; Couvreur, P.; Chem. Commun. 2014, 50, 5336.

61. Saha, D.; Testard, F.; Grillo, I.; Zouhiri, F.; Desmaele, D.; Radulescu, A.; Desert, S.; Brulet, A.; Couvreur, P.; Spalla, O.; Soft Matter 2015, 11, 4173.

62. Beltrán, G.; Bucheli, M. E.; Aguilera, M. P.; Belaj, A.; Jimenez, A.; Eur. J. Lipid Sci. Technol. 2016, 118, 1250.

63. Gaforio, J. J.; Sánchez-Quesada, C.; López-Biedma, A.; Ramírez-Tortose, M. C.; Warleta, F. In The Mediterranean Diet; Preedy, V.; Watson, R., eds.; Elsevier: Amsterdam, 2015, p. 281.

64. Newmark, H. L.; Ann. N. Y. Acad. Sci. 1999, 889, 193.

65. Abraham, A.; Kattoor, A. J.; Saldeen, T.; Mehta, J. L.; Crit. Rev. Food Sci. Nutr. 2018, DOI: 10.1080/10408398.2018.1474169.

66. Wang, H.; Hong, J.; Yang, C. S.; Mol. Carcinog. 2016, 55, 1728.

67. Huang, H.; He, Y.; Cui, X. X.; Goodin, S.; Wang, H.; Du, Z. Y.; Li, D.; Zhang, K.; Tony Kong, A. N.; DiPaola, R. S.; Yang, C. S.; Conney, A. H.; Zheng, X.; J. Agric. Food Chem. 2014, 62, 10752.

68. Sato, C.; Kaneko, S.; Sato, A.; Virgona, N.; Namiki, K.; Yano, T.; J. Nutr. Sci. Vitaminol. 2017, 63, 349.

69. Moore, C. A.; Palau, V.; Lightner, J.; Brannon, M.; Stone, W.; Krishnan, K.; J. Clin. Oncol. 2017, 35, e13043.

Submitted: April 16, 2019 Published online: August 6, 2019 